\title{
Drugs for Combined Therapy: Experimental Studies on the Antileprosy Activity of Ethionamide and Prothionamide, and a General Review
}

\author{
M. J. COLSTON \\ St George's Hospital Medical School, London SW17 ORE, U.K. \\ G. A. ELLARD AND PATRICIA T. GAMMON \\ MRC Unit for Laboratory Studies of Tuberculosis \\ Royal Postgraduate Medical School, \\ Ducane Road, London W12 OHS, U.K.
}

\begin{abstract}
The activity of ethionamide and prothionamide against Mycobacterium leprae has been evaluated using the mouse footpad model. The minimum effective doses of both drugs were found to be approximately $0.01 \%$, and their minimal inhibitory concentrations were estimated to be about $0.05 \mu \mathrm{g} / \mathrm{ml}$. Both compounds were found to be bactericidal against $M$. leprae at dietary concentrations of $0.1 \%$. These findings indicate the importance of studies to evaluate the potential role of ethionamide and prothionamide in clinical practice. The available experimental evidence concerning the relative antileprosy activities of drugs that might be used in the combined treatment of lepromatous patients is reviewed.
\end{abstract}

\section{Introduction}

The importance of finding new antileprosy drugs for use in combined treatment to combat the growing problem posed by the widespread emergence of dapsone-resistant strains of Mycobacterium leprae was discussed in the previous paper (Colston et al., 1978b). In the current paper we report the determination of the minimum effective doses (MEDs) of ethionamide and prothionamide against several strains of $M$. leprae using the mouse footpad technique. Estimations of the minimal inhibitory concentrations (MICs) of these 2 drugs against $M$. leprae are also described, together with studies to assess the extent of their bactericidal activity. Finally we review current knowledge concerning the relative activities of the presently available antileprosy drugs.

The antituberculosis drug ethionamide ( $\alpha$-ethyl thioisonicotinamide) has been used to a limited extent in the treatment of leprosy, but has not gained 
widespread acceptance because of the relatively high incidence of gastric intolerance when it is given at dose levels normally used for the treatment of tuberculosis (500-750 mg per day). The most extensive study of ethionamide in the treatment of leprosy was made by Rollier and Rollier (1972), who treated 102 lepromatous patients with an initial dosage of $1 \mathrm{~g}$ per day. However, because of side effects, they subsequently reduced the daily dosage to $500 \mathrm{mg}$ for adults and $250 \mathrm{mg}$ for children. They concluded that the lower dosage of ethionamide was well tolerated, and after 4 years treatment most of the patients had a Bacterial Index of zero. The acceptability of lower doses of ethionamide accords with the excellent tolerance of the drug encountered when it was given at a dosage of $250 \mathrm{mg}$ per day in the earlier study of Floch, Rist and Jacobi (1966).

Prothionamide ( $\alpha$-propyl thioisonicotinamide), the propyl analogue of ethionamide, has largely replaced ethionamide in the treatment of tuberculosis, since its activity against $M$. tuberculosis is equal or slightly superior to that of ethionamide (Grumbach et al., 1956; Rist, 1960; Noufflard-Guy-Loé and Berteaux, 1962), and because patients have generally been found to tolerate prothionamide slightly better than ethionamide (Bruet, Chevallier and Névot, 1962; Molina et al., 1964; Chambatte et al., 1965; Martin-Lalande et al., 1966; British Tuberculosis Association, 1968; Co-operative Study Unit on Chemotherapy of Tuberculosis of the National Sanatoria in Japan, 1968; Fox et al., 1969). Freerksen (1975) has advocated the use of prothionamide in combination treatment, but it is difficult to assess from published reports the precise dosage of prothionamide employed by his collaborators.

In the mouse footpad, ethionamide has been found to be inactive against $M$. leprae when fed at $0.001 \%$ in the diet, bacteriostatic at $0.01 \%$, and bactericidal at $0.1 \%$ or $0.2 \%$ (Shepard, 1969a,b, 1976). Prothionamide has not been tested previously for antileprosy activity in the mouse footpad.

\section{Methods}

\section{DETERMINATION OF THE MINIMUM EFFECTIVE DOSES}

The minimum effective doses (MEDs) of ethionamide and prothionamide were determined using the methods described in the accompanying paper (Colston et al., 1978b). Three strains of M. leprae were used (SBL 16220, SBL 15337 and TG), and the 2 drugs were administered at dietary concentrations of $0.001 \%, 0.003 \%, 0.01 \%$ and $0.03 \%$ commencing on the day of inoculation and continuing throughout the experiment.

\section{ASSESSMENT OF BACTERICIDAL ACTIVITY}

Ethionamide and prothionamide were administered to mice infected with $M$. leprae strain TG at dietary concentrations of $0.03 \%, 0.1 \%$ and $0.2 \%$, starting on the day of inoculation and continuing for 60 days. Monitoring of bacillary growth and assessment of bactericidal activity were carried out as described previously (Colston et al., 1978b). 


\section{DETERMINATION OF MOUSE SERUM CONCENTRATIONS OF ETHIONAMIDE AND PROTHIONAMIDE}

Because of the insensitivity of currently available ultraviolet methods for determining ethionamide and prothionamide in the serum (see Jenner and Ellard, 1978), and the small amounts of serum obtainable from mice, a radiochemical method was devised for measuring mouse serum ethionamide and prothionamide concentrations using the same basic approach as that described for the determination of thiacetazone (Colston et al., 1978b). A novel gas-liquid chromatographic procedure, capable of measuring down to about $0.2 \mu \mathrm{g}$ ethionamide or prothionamide in $1 \mathrm{ml}$ serum, was also devised and used to analyse sera from mice fed with the highest dietary concentrations of the 2 drugs $(0.2 \%)$.

\section{(a) Radiochemical method}

Batches of ${ }^{14} \mathrm{C}$-labelled ethionamide or prothionamide, with specific activities ranging from about $0.05-1 \mathrm{mCi} / \mathrm{mM}$ were prepared for feeding to mice at dietary concentrations of $0.2 \%-0.01 \%$, respectively, by mixing methanolic solutions containing $1 \mathrm{mg} / \mathrm{ml}$ of ethionamide or prothionamide labelled in the thiocarbamyl group, and unlabelled ("cold") drug, and evaporating to dryness under reduced pressure.

Groups of 10 mice were fed for $24 \mathrm{~h}$ on diet containing $0.01 \%, 0.03 \%, 0.1 \%$ and $0.2 \%{ }^{14} \mathrm{C}$ labelled ethionamide or prothionamide, and the concentrations of the drugs determined in pooled serum. In order to ascertain whether prolonged administration might induce the metabolism of these drugs, other groups of mice were fed $0.1 \%$ unlabelled ethionamide or prothionamide for 14 days prior to feeding $0.1 \%$ of the ${ }^{14} \mathrm{C}$-labelled formulations in the diet for $24 \mathrm{~h}$ and determining the serum concentrations of the 2 drugs.

A $1 \mathrm{ml}$ aliquot of serum from mice fed for $24 \mathrm{~h}$ on diet containing ${ }^{14} \mathrm{C}$-labelled ethionamide or prothionamide was pipetted into a small centrifuge tube together with $0.1 \mathrm{ml}$ of a methanolic solution containing $1 \mathrm{mg} / \mathrm{ml}$ "cold" ethionamide or prothionamide to act as a "marker" to estimate the recovery of the drugs in the separation system, and ethionamide/prothionamide extracted by shaking with $2 \mathrm{ml}$ ether. This solvent was chosen to minimize any potential contribution from sulphoxide metabolites of the drugs to the assay (Kane, 1962). After centrifugation the upper organic phase was decanted using a Pasteur pipette and then extracted by shaking with $0.5 \mathrm{ml} 0.1 \mathrm{~N}$ hydrochloric acid. The lower acid extract was then transferred to another centrifuge tube, $0.1 \mathrm{ml} \mathrm{M}$ dipotassium hydrogen phosphate added and the ethionamide/prothionamide extracted by shaking with $0.1 \mathrm{ml}$ chlorof orm.

The chloroform extract was dried onto a silica gel thin layer chromatography plate (Merck) and then developed with acetone/methanol $(1: 1 \mathrm{v} / \mathrm{v})$ for $50 \mathrm{~min}$. After drying and examining under ultraviolet light, the u.v.-absorbing spot was scraped off and eluted by shaking with $2 \mathrm{ml}$ methanol in a small centrifuge tube. This was centrifuged and the overall recovery of ethionamide/prothionamide in the combined separation procedure was determined by measuring the extinction of the methanol extract at its absorption maximum (approximately $290 \mathrm{~nm}$ ). A $1.5 \mathrm{ml}$ aliquot of the methanol extract was then dried down in a scintillation vial, $5 \mathrm{ml}$ of $0.6 \%$ butyl-PBD in toluene added and counted in a scintillation counter. The concentration of ethionamide/prothionamide in the original mouse serum could then be estimated by calculating the ratio of the extract'sradioactivity [(counts per min) absorbance] and comparing it with the ratio for standards prepared from the appropriate ${ }^{14} \mathrm{C}$-labelled thioamide preparation in blank serum, taken through the same procedure.

\section{(b) Gas-liquid chromatographic method}

A $1 \mathrm{ml}$ aliquot of serum was pipetted into a small centrifuge tube together with $0.1 \mathrm{ml}$ of a methanolic solution containing $10 \mu \mathrm{g} / \mathrm{ml}$ ethionamide/prothionamide (prothionamide for the determination of ethionamide; ethionamide for the determination of prothionamide) to act as internal standard and extracted by shaking with $4 \mathrm{ml}$ ether. After centrifugation, the ether extract was extracted with $1 \mathrm{ml} 0.1 \mathrm{~N}$ hydrochloric acid. The acid extract was then transferred to 
another centrifuge tube and the thioamides extracted into $1 \mathrm{ml}$ chloroform after the addition of $0.2 \mathrm{ml} \mathrm{M}$ dipotassium hydrogen phosphate. The chloroform extract was transferred to a small tapered centrifuge tube, evaporated to dryness at $50^{\circ} \mathrm{C}$ under a stream of nitrogen and the residue redissolved in $20 \mu \mathrm{l}$ chloroform, from which aliquots of $1 \mu \mathrm{l}$ were injected onto the gas-liquid chromatography column.

Chromatography was carried out at $160^{\circ} \mathrm{C}$ on a coiled glass column $(7 \mathrm{ft}$ long $\times 2 \mathrm{~mm}$ i.d. $)$ silanized with dimethyldichlorosilane and packed with 3\% OV-225 on Gas Chrom Q (100-120 mesh) using a Pye 104 instrument equipped with a flame-ionization detector. The injector and detector were maintained at $170^{\circ}$ and $250^{\circ}$, respectively, and the flow-rates were carrier gas (nitrogen) 25, air 600 and hydrogen $50 \mathrm{ml} / \mathrm{min}$. Under these conditions the approximate retention times of ethionamide and prothionamide were 1.6 and $2.2 \mathrm{~min}$, respectively, and a linear relationship was obtained between the ratios of the peak heights of test drug to internal standard for initial ethionamide/prothionamide concentrations of 0.2 to $5 \mu \mathrm{g} / \mathrm{ml}$.

\section{Results}

The results of the studies to determine the minımum effective doses of ethionamide and prothionamide are summarized in Table 1 . The growth of the 3 strains of $M$. leprae was partially suppressed by feeding $0.003 \%$ ethionamide in the diet, and totally suppressed by $0.01 \%$, confirming the results previously obtained by Shepard (1969a). The multiplication of strains SBL 15337 and TG was completely prevented by feeding $0.01 \%$ prothionamide, although $0.03 \%$ was required to entirely suppress the growth of strain SBL 16220. It was therefore concluded that the MEDs of both drugs were approximately $0.01 \%$.

TABLE 1

Estimation of the minimum effective dose (MED) of ethionamide and prothionamide against M. leprae

\begin{tabular}{cccccc}
\hline $\begin{array}{c}\text { M. leprae } \\
\text { strain }\end{array}$ & 0.001 & 0.003 & 0.01 & 0.03 & MED \\
\hline SBL 16220 & - & $\begin{array}{c}\text { Ethionamide } \\
5 / 6 \dagger\end{array}$ & $0 / 6$ & $0 / 6$ & $0.01 \%$ \\
SBL 15337 & - & $4 / 6$ & $0 / 6$ & $0 / 6$ & $0.01 \%$ \\
TG & $6 / 6$ & $5 / 6$ & $0 / 6$ & - & $0.01 \%$ \\
& & & & \\
SBL 16220 & - & Prothionamide & & \\
SBL 15337 & - & $6 / 6$ & $2 / 6$ & $0 / 6$ & $0.03 \%$ \\
TG & $6 / 6$ & $4 / 6$ & $0 / 6$ & $0 / 6$ & $0.01 \%$ \\
\hline
\end{tabular}

* Not tested.

$\dagger$ Number of footpads positive/number of footpads harvested.

The concentrations of ethionamide and prothionamide in the serum of mice fed various dosages of the 2 drugs determined using the radiochemical method are illustrated in Fig. 1 . The results obtained when mice were fed $0.2 \%$ of the drugs in the diet were confirmed using the gas-liquid chromatographic method. Serum concentrations of both drugs were approximately proportional to the percentages fed in the diet, and, since there was no significant difference between the results obtained for ethionamide and prothionamide, a single regression line was plotted. The serum concentrations of ethionamide and pro- 


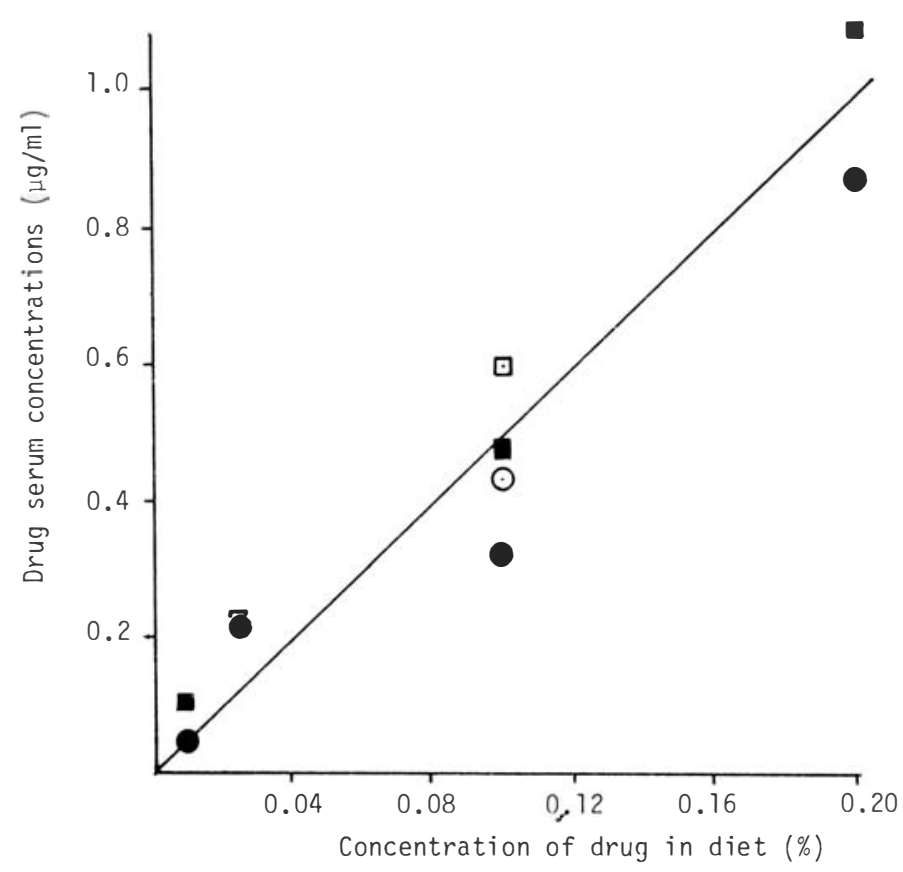

Fig. 1. Serum concentrations of ethionamide $(\bullet)$ and prothionamide $(\square)$ of mice fed for $24 \mathrm{~h}$ on diet containing graded doses of ${ }^{14} \mathrm{C}$-labelled drug. Open symbols $(\odot, \odot)$ represent the values obtained in mice fed for 14 days with unlabelled drug, followed by labelled drug for $24 \mathrm{~h}$.

thionamide in mice that had been fed with the drugs for 14 days were no lower than those that had only been fed on drug-containing diets for $24 \mathrm{~h}$, indicating that the metabolism of neither drug had been induced.

The minimal inhibitory concentrations (MICs) of both ethionamide and prothionamide against $M$. leprae, defined as the serum concentrations present in mice fed with the MEDs of the 2 drugs $(0.01 \%)$, were estimated from the data illustrated in Fig. 1 as being about $0.05 \mu \mathrm{g} / \mathrm{ml}$. Thus, as had been previously demonstrated with $M$. tuberculosis, both drugs appear to have rather similar antimycobacterial activity.

The results of the kinetic experiment to assess the potential bactericidal activity of the 2 drugs are summarized in Table 2. Neither ethionamide nor prothionamide showed any bactericidal activity when administered for 60 days at $0.03 \%$ as indicated by excess growth delays of only 16 days. However, when the dietary concentration was increased to $0.1 \%$, multiplication of bacilli could not be detected for periods of up to 442 days post inoculum when the final harvest was made. The excess growth delay, calculated by drawing a line through the final point parallel to the growth curve for the untreated controls, was 215 days for ethionamide and 225 days for prothionamide. The excess growth delay engendered by feeding $0.2 \%$ ethionamide for 60 days was 209 days, while in the single mouse fed on $0.2 \%$ prothionamide and sacrificed at day 442 after inoculation, there was no evidence of multiplication of M. leprae. 
TABLE 2

Assessment of antibacterial activity by the kinetic technique: the effect of feeding of graded doses of ethionamide and prothionamide in the diet on the growth of $\mathrm{M}$. leprae in mouse footpads

\begin{tabular}{llcc}
\hline \multicolumn{1}{c}{ Drug } & Dose* & $\begin{array}{c}\text { Growth delay } \\
\text { (days) }\end{array}$ & $\begin{array}{c}\text { Excess growth delay† } \\
\text { (days) }\end{array}$ \\
\hline Ethionamide & $0.03 \%$ & 76 & 16 \\
& $0.1 \%$ & 275 & $215 \ddagger$ \\
& $0.2 \%$ & 269 & $209 \ddagger$ \\
Prothionamide & $0.03 \%$ & 75 & 16 \\
& $0.1 \%$ & 285 & $225 \ddagger$ \\
& $0.2 \%$ & $>332$ & $>272$ \\
\hline
\end{tabular}

* Drug administered for 60 days, from day 0 .

+ Growth delay less period of drug administration.

$\ddagger$ Estimate based on 1 positive footpad count.

These results indicate that feeding mice with $0.1 \%$ or $0.2 \%$ ethionamide or prothionamide resulted in significant killing of $M$. leprae, confirming the findings previously reported by Shepard for ethionamide (Shepard, 1969a,b, 1976). The similarity in the bactericidal activities displayed by ethionamide and prothionamide is also in accord with the results obtained using the more rigorous proportional bactericidal test method (Colston, Hilson and Banerjee, 1978). The bactericidal activity of ethionamide against $M$. leprae parallels that previously demonstrated against $M$. tuberculosis both in vitro and in vivo in the mouse (Dickinson and Mitchison, 1966; Rist et al., 1958).

\section{Discussion}

\section{ANTILEPROSY ACTIVITY OF ETHIONAMIDE AND PROTHIONAMIDE}

The results obtained in this investigation indicate that these 2 drugs deserve serious consideration as candidates for use in the combined treatment of lepromatous leprosy. The minimal inhibitory concentrations of ethionamide and prothionamide against $M$. leprae determined in this study using the mouse footpad model were about $0.05 \mu \mathrm{g} / \mathrm{ml}$, or about a tenth of the MICs originally reported against $M$. tuberculosis using conventional in vitro techniques (Grumbach et al., 1956; Rist, 1960; Noufflard-Guy-Loé and Berteaux, 1962). It would however be unwise to conclude that $M$. leprae is necessarily much more sensitive than $M$. tuberculosis to inhibition by the thioamides, since it is possible that the sulphoxide metabolites of the 2 drugs that are formed in man and in the mouse (Kane, 1962; Johnson, Kane and Kibby, 1967; Rossi and Rübsammen, 1977) and have significant antituberculosis activity (Libermann, Rist and Grumbach, 1963; J. Peters and T. Welch, pers. comm., 1978) might also contribute to their antileprosy activity in vivo.

Peak serum concentrations of ethionamide and prothionamide are approximately proportional to dose, with concentrations of about $3 \mu \mathrm{g} / \mathrm{ml}$ being achieved after giving $500 \mathrm{mg}$ of either drug (Riddell, 1960; Gray, Hamilton 
and Eidus, 1962; Hughes, Smith and Kane, 1962; D. F. Muggleton, pers. comm., 1965; Jenner and Ellard, 1978). This suggests that, at this dose, peak serum concentrations of the drugs would exceed their MICs against $M$. leprae by a factor of approximately 60 -fold. Thereafter serum concentrations fall with a half-life of about $2 \mathrm{~h}$ and by $24 \mathrm{~h}$ are of the same order as the MIC against M. leprae (Jenner and Ellard, 1978). Since significant bactericidal activity against $M$. leprae was demonstrated when ethionamide or prothionamide were fed to mice at $0.1 \%$, and since such dietary concentrations gave rise to serum concentrations of about $0.5 \mu \mathrm{g} / \mathrm{ml}$, there would seem to be reasonable grounds for hoping that bactericidal activity might be achieved in clinical practice if daily doses of $250-500 \mathrm{mg}$ were given. Furthermore, in view of the established dose dependence of gastric intolerance of the 2 drugs and the appreciably better acceptability of prothionamide, it is likely that daily dosage with $250 \mathrm{mg}$ prothionamide would be excellently tolerated by patients.

\section{REVIEW OF EXPERIMENTAL EVIDENCE CONCERNING THE RELATIVE ACTIVITIES OF ANTILEPROSY DRUGS}

The experimental data currently available concerning the relative activities of antileprosy drugs are summarized in Table 3. This Table shows the MICs of the drugs against $M$. leprae determined in the mouse footpad system, the ratios of peak serum concentrations to MIC for doses of the drugs that are well tolerated by patients, the durations for which serum concentrations exceed the MIC after such doses and the degree of bactericidal activity assessed using the proportional bactericidal test method (Colston et al., 1978a).

TABLE 3

Minimal inhibitory concentrations against M. leprae (MICs), peak serum concentrations, durations of coverage and bactericidal activities of antileprosy drugs

\begin{tabular}{|c|c|c|c|c|c|}
\hline Drug & $\begin{array}{c}\text { MIC } \\
(\mu \mathrm{g} / \mathrm{ml})\end{array}$ & $\begin{array}{l}\text { Dosage } \\
(\mathrm{mg})\end{array}$ & $\begin{array}{c}\text { Ratio } \\
\text { peak serum } \\
\text { MIC }\end{array}$ & $\begin{array}{l}\text { Duration for } \\
\text { which serum } \\
\text { concs exceed } \\
\text { MIC (days) }\end{array}$ & $\begin{array}{c}\text { Bactericidal§ } \\
\text { activity }\end{array}$ \\
\hline Dapsone & 0.003 & 100 & 500 & 10 & + \\
\hline Acedapsone & $0.003^{*}$ & 225 & 15 & 200 & N.T. $\dagger$ \\
\hline Rif ampicin & 0.3 & 600 & 30 & 1 & +++ \\
\hline Sulphadimethoxine & 20 & 1500 & 7 & 4 & N.T. \\
\hline Sulphadoxine & 35 & 1500 & 4 & 14 & N.T. \\
\hline Sulphamethoxypyridazine & 30 & 1000 & 3 & 3 & N.T. \\
\hline Thiambutosine & 0.5 & 1500 & 1 & $<1$ & - \\
\hline Thiacetazone & 0.2 & 150 & 8 & 1 & - \\
\hline Ethionamide $\ddagger$ & 0.05 & 500 & 60 & 1 & ++ \\
\hline Prothionamide $\ddagger$ & 0.05 & 500 & 60 & 1 & ++ \\
\hline
\end{tabular}

* Acedapsone is inactive against M. leprae but is converted to dapsone - the figures for MIC and peak serum concentration refer to the values for dapsone.

$\dagger$ Not tested.

$\ddagger$ Results obtained in the present study.

$\S-$, Purely bacteriostatic;,,++++++ , relative degrees of bactericidal activity. 
A considerable body of evidence is available concerning the activity and pharmacology of the clinically established drugs dapsone, acedapsone (DADDS), and rifampicin. The MIC of dapsone was shown by Peters et al. $(1975 b)$ and Levy and Peters (1976) to be about $0.003 \mu \mathrm{g} / \mathrm{ml}$. Since peak serum levels in man following a dose of $100 \mathrm{mg}$ dapsone are approximately $1.5 \mu \mathrm{g} / \mathrm{ml}$ (Glazko et al., 1968; Peters, Gordon and Karat, 1975; Committee on Experimental Chemotherapy, 1976), the ratio of peak serum concentration to MIC is approximately 500. The serum half-life of dapsone has now been determined in over 200 patients, and found to vary from 13-53 h (Peters et al., 1972; Ellard, Gammon and Harris, 1974; Peters et al., 1974; Gelber and Rees, 1975; Peters et al., 1975a, 1976, 1977). Assuming a representative value of $27 \mathrm{~h}$, one can calculate that a $100 \mathrm{mg}$ dose of dapsone will maintain serum concentrations in excess of the MIC for about 10 days.

Dapsone serum levels in excess of the MIC against $M$. leprae can be maintained for much longer periods by intramuscular injection of acedapsone (Glazko et al., 1968; Ozawa et al., 1971) A dose of $225 \mathrm{mg}$ acedapsone produces mean peak dapsone plasma concentrations of $0.046 \mu \mathrm{g} / \mathrm{ml}$, approximately 15 times the MIC, and it may be calculated from the data published by Peters et al., (1977) that plasma concentrations would be maintain above the MIC for about 200 days.

The MIC of rifampicin has been estimated as $0.3 \mu \mathrm{g} / \mathrm{ml}$ (Holmes and Hilson, 1972; Holmes, 1974), and since serum plasma concentrations after dosage with $600 \mathrm{mg}$ are approximately $10 \mu \mathrm{g} / \mathrm{ml}$, with a half-life of $2-3 \mathrm{~h}$ (Furesz et al., 1967; Dans et al., 1970; Acocella et al., 1971, 1972; Jeanes, Jessamine and Eidus, 1972; Boman, 1974; Garnham et al., 1976; Männistö, 1977), the ratio of peak serum concentration to MIC is about 30 -fold with inhibitory serum levels being maintained for about $24 \mathrm{~h}$. It should however be noted that more recent estimates of the MED of rif ampicin against $M$. leprae (Waters et al., 1978) are approximately 4 times that originally determined by Holmes and Hilson (1972).

The pertinent data for sulphadimethoxine and sulphadoxine were reported earlier (Ellard, Gammon and Rees, 1970), while the studies from which the values for sulphamethoxypyridazine, thiambutosine and thiacetazone were derived are described in the accompanying paper (Colston et al., 1978b). The relative bactericidal activities shown in the last column of Table 3 were determined using the proportional bactericidal test method (Colston et al., $1978 a$ ). The doses of drugs tested in that investigation probably gave serum concentrations in mice that are similar to those achieved in patients under treatment and the relative bactericidal potencies determined experimentally in this way correlated closely with those realized in clinical practice. Corresponding data are not available for clof azimine since its accumulation in reticulo-endothelial cells makes it impossible to estimate its MIC against $M$. leprae (Banerjee et al., 1974; Levy, 1974), although it is likely that after an extended period of treatment effective concentrations would be maintained for many weeks. Its bactericidal activity assessed using the proportional bactericidal test method was intermediate between that of dapsone and rif ampicin (Colston et al., 1978a). 
It must be emphasized that the data assembled in Table 3 are very imprecise since the MIC determinations only have the precision with which the MEDs of the drugs have been estimated and because it is usually only practicable to determine MEDs using dietary doses differing by factors of at least 3-fold. Nevertheless the markedly superior ratios of peak serum concentrations to MIC, durations of coverage and estimates of the bactericidal activity displayed by the 2 most clinically potent antileprosy drugs, dapsone and rifampicin, indicate the potential relevance of such properties in attempting to assess the prospects of other medicaments that have yet to be evaluated using properly monitored controlled clinical trials. Thus the substantially lower peak serum/MIC ratios of sulphadimethoxine, sulphadoxine and sulphamethoxypyridazine suggest that the use of these long-acting sulphonamides should be discontinued.

The cross-resistance known to exist with $M$. tuberculosis between the diphenylthioureas, thiacetazone and thioamides (Rist et al., 1959; Bartmann, 1960; Grosset and Benhassine, 1970) indicates that a similar phenomenon might occur for $M$. leprae and that these drugs should therefore be regarded as belonging to the same general class. The evidence summarized in Table 3 and discussed in detail in the previous paper (Colston et al., 1978b) suggests that thiacetazone is a much better candidate for use in combined therapy than thiambutosine. However the results of the present study indicate that ethionamide and prothionamide are even more promising and strongly encourage the initiation of detailed investigations into the clinical and bacteriological efficacy of the 2 drugs.

\section{Acknowledgements}

This work was supported in part by Grant No. G. 976/766 of the Overseas Development Administration, London, and by the World Health Organization as part of the THELEP programme. We should also like to thank Dr M. Davis of May and Baker and Dr P. Frechet, formerly of Theraplix, for their help in obtaining samples of ${ }^{14} \mathrm{C}$-labelled ethionamide and prothionamide.

\section{References}

Acocella, G., Bonollo, L., Garimoldi, M., Mainardi, M., Tenconi, L. T. and Nicolis, F. B. (1972). Kinetics of rifampicin and isoniazid administered alone and in combination to normal subjects and patients with liver disease. Gut 13, 47 .

Acocella, G., Pagani, V., Marchetti, M., Baroni, G. C. and Nicolis, F. B. (1971). Kinetic studies on rifampicin. Chemotherapy 16, 356.

Baner jee, D. K., Ellard, G. A., Gammon, P. T. and Waters, M. F. R. (1974). Some observations on the pharmacology of clof azimine (B663). Am. J. trop. Med. Hyg. 23, 1110.

Bartmann, K. (1960). Kreuzresistenz zwischen $\alpha$-Äthylthioisonicotinamid (1314 TH) und Thiosemicarbazon (Conteben). Tuberk. Arzt. 14, 525.

Boman, G. (1974). Serum concentration and half-life of rifampicin after simultaneous oral administration of aminosalicylic acid or isoniazid. Europ. J. clin. Pharmacol. 7, 217.

British Tuberculosis Association (1968). A comparison of the toxicity of prothionamide and ethionamide. Tubercle 49, 125. 
Brouet, G., Chevallier, J. and Névot, P. (1962). Etude préliminaire du 1321 Th ou thioamide de l'acide alpha-propyl-isonicotinique dans la tuberculose pulmonaire commune de l'homme. Rev. Tuberc. (Paris) 26, 1187.

Chambatte, C., Kermarec, J., Haguenauer, G., Page, G. and Bach, J. F. (1965). Essais cliniques du thioamide de l'acide alpha-propyl-isonicotinique $(1321 \mathrm{TH})$ dans le traitement de la tuberculose humaine. Tolérance, toxicité viscérale comparées à celles de $1314 \mathrm{Th}$ (A propos de 21 cas traités pendant deux mois et de 70 cas traités pendant trois mois). Rev. Tuberc. (Paris) 29, 33.

Colston, M. J., Hilson, G. R. F. and Banerjee, D. K. (1978a). The "proportional bactericidal test": a method for assessing bactericidal activity of drugs against Mycobacterium leprae in mice. Lepr.Rev. 49, 7.

Colston, M. J., Hilson, G. R. F., Ellard, G. A., Gammon, P. T. and Rees, R. J. W. (1978b). The activity of thiacetazone, thiambutosine, thiocarlide and sulphamethoxypyridazine against Mycobacterium leprae in mice. Le pr.Rev. 49, 101.

Committee on Experimental Chemotherapy (1976). Experimental chemotherapy of leprosy. Bull. Wld Hlth Org. 53, 425.

Co-operative Study Unit on Chemotherapy of Tuberculosis of the National Sanatoria in Japan (1968). Comparison of the clinical usefulness of ethionamide and prothionamide in initial treatment: tenth series of controlled trials. Tubercle 49, 281.

Dans, P. E., McGehee, R. F., Wilcox, C. and Finland, M. (1970). Rifampin: antibacterial activity in vitro and absorption and excretion in normal young men. Am. J. med. Sci. 259, 120.

Dickinson, J. M. and Mitchison, D. A. (1966). In vitro studies on the choice of drugs for intermittent chemotherapy of tuberculosis. Tubercle 47, 370.

Ellard, G. A., Gammon, P. T. and Harris, J. M. (1974). The application of urine tests to monitor the regularity of dapsone self-administration. Lepr. Rev. 45, 224.

Ellard, G. A., Gammon, P. T. and Rees, R. J. W. (1970). The minimal inhibitory concentrations of sulphadimethoxine and sulphadoxine against Mycobacterium leprae. Lepr. Rev. 41, 223.

Floch, H., Rist, N. and Jacobi, J. (1966). Intérêt de l'éthionamide en thérapeutique antilépreuse. Bull. Soc. Path. exot. 59, 715.

Fox, W., Robinson, D. K., Tall, R., Mitchison, D. A., Kent, P. W. and Macfadyen, D. M. (1969). A study of acute intolerance to ethionamide, including a comparison with prothionamide, and of the influence of a vitamin B-complex additive in prophylaxis. Tubercle 50, 125.

Freerksen, E. (1975). The technique of evaluating anti-leprosy medications at the Forschungsinstitut Borstel. Lepr. Rev. 46 (Suppl.), 25.

Furesz, S., Scotti, R., Pallanza, R. and Mapelli, E. (1967). Rifampicin: a new rifamycin. III: Absorption, distribution and elimination in man. Arzneimittel-Forsch. 17, 534.

Garnham, J. C., Taylor, T., Turner, P. and Chasseaud, L. F. (1976). Serum concentrations and bioavailability of rif ampicin and isoniazid in combination. Br. J. clin. Pharmac. 3, 897.

Gelber, R. H. and Rees, R. J. W. (1975). Dapsone metabolism in patients with dapsone-resistant leprosy. Am. J. trop. Med. Hyg. 24, 963.

Glazko, A. J., Dill, W. A., Montalbo, R. G. and Holmes, E. L. (1968). A new analytical procedure for dapsone. Application to blood-levels and urinary-excretion studies in normal men. Am. J. trop. Med. Hyg. 17, 465.

Gray, D. G., Hamilton, E. J. and Eidus, L. (1962). Clinico-laboratory studies of alphaethylthioisonicotinamide (TH 1314). Canad. med. Ass. J. 86, 317.

Grosset, J. and Benhassine, M. (1970). La thiacetazone $\left(\mathrm{Tb}_{1}\right)$ : donées expérimentales et cliniques récentes. Adv. Tuberc. Res. 17, 107.

Grumbach, F., Rist, N., Libermann, D., Moyeux, M., Cals, S. and Clavel, S. (1956). Activite antituberculeuse expérimentale de certains thioamides isonicotiques substitués sur le noyau. C. R. Acad.Sci.(Paris) 242, 2187.

Holmes, I. B. (1974). Minimum inhibitory and bactericidal dosages of rifampicin against Mycobacterium leprae in the mouse foot-pad: relationship to serum rifampicin concentrations. Int. J. Lepr. 42, 289.

Holmes, I. B. and Hilson, G. R. F. (1972). The effect of rif ampicin and dapsone on experimental Mycobacterium leprae infections: minimum inhibitory concentrations and bactericidal action. J. med. Microbiol. 5, 251. 
Hughes, I. E., Smith, H. and Kane, P. O. (1962). Ethionamide: its passage into the cerebrospinal fluid in man. Lancet $i, 616$.

Jeanes, C. W. L., Jessamine, A. G. and Eidus, L. (1972). The treatment of chronic drug-resistant pulmonary tuberculosis with rif ampicin and ethambutol. Canad. med. Ass. J. 106, 884.

Jenner, P. J. and Ellard, G. A. (1978). A high pressure liquid chromatographic method for the determination of ethionamide and prothionamide in plasma or urine. (In preparation.)

Johnston, J. P., Kane, P. O. and Kibby, M. R. (1967). The metabolism of ethionamide and its sulphoxide. J. Pharm. Pharmac. 19, 1.

Kane, P. O. (1962). Indentification of a metabolite of the antituberculous drug ethionamide. Nature 195, 495.

Levy, L. (1974). Pharmacologic studies of clof azimine. Am. J. trop. Med. Hyg. 23, 1097.

Levy, L. and Peters, J. H. (1976). Susceptibility of Mycobacterium leprae to dapsone as a determinant of patient response to acedapsone. Antimicrob. Agents Chemother. 9, 102.

Libermann, D., Rist, N. and Grumbach, F. (1963). Le S-oxyde de $1^{\prime} \alpha$-éthylthioamide isonicotique. C. R. Acad. Sci. (Paris) 257, 307.

Männistö, P. (1977). Absorption of rifampin from various preparations and pharmaceutic forms. Clin. Pharmacol. Therap. 21, 370.

Martin-Lalande, J., Jaubertie, R., D jebbar, A. and Pham Trong Quyen. (1966). Etude clinique et biologique de la tolérance au tuberculostatique $1321 \mathrm{TH}$ (prothionamide). (Tolérance à long term, tolérance comparée avec le 1314 Th employé préablement ou successivement (238 cas)). Rev. Tuberc. (Paris) 30, 1233.

Molina, C., Sirot, J., Cheminat, J. Cl. and Petit. R. (1964). Le thioamide de l'acide alpha-propylisonicotinique (ou $1321 \mathrm{Th}$ ) dans le traitement de la tuberculose pulmonaire. Rev. Tuberc. (Paris) 28, 1261.

Noufflard-Guy-Loé, H. and Berteaux, S. (1962). Etude expérimentale de l'activité antituberculeuse d'un thioamide isonicotinique voisin de l'éthionamide: Le $1321 \mathrm{Th}$ (9,778 R. P.). Rev. Tuberc. (Paris) 26, 1204.

Ozawa, T., Shepard, C. C. and Karat, A. B. A. (1971). Application of spectrophotofluorometric procedures to some problems in Mycobacterium leprae infections in mice and man treated with dapsone (DDS) diacetyl-DDS (DADDS), and di-formyl-DDS (DFD). Am. J. trop. Med. Hyg. 20, 274.

Peters, J. H., Gordon, G. R., Ghoul, D. C., Tolentino, J. G. Walsh, G. P. and Levy, L. (1972). The disposition of the antileprotic drug dapsone (DDS) in Philippine subjects. Am. J. trop. Med. Hyg. 21, 450.

Peters, J. H., Gordon, G. R. and Karat, A. B. A. (1975a). Polymorphic acetylation of the antibacterials, sulfamethazine and dapsone, in South Indian subjects. Am. J. trop. Med. Hyg. 24, 641.

Peters, J. H., Gordon, G. R., Levy, L., Storkan, M. A., Jacobsen, R. R., Enna, C. D. and Kirchheimer, W. F. (1974). Metabolic disposition of dapsone in patients with dapsoneresistant leprosy. Am. J. trop. Med. Hyg. 23, 222.

Peters, J. H., Gordon, G. R., Murray, J. F., Fieldsteel, A. H. and Levy, L. (1975b). Minimal inhibitory concentration of dapsone for Mycobacterium leprae in rats. Antimicrob. Agents Chemother. 8, 551.

Peters, J. H., Murray, J. F., Gordon, G. R., Levy, L., Russell, D. A., Scott, G. C., Vincin, D. R. and Shepard, C. C. (1977). Acedapsone treatment of leprosy patients: response versus drug disposition. Am. J. trop. Med. Hyg. 26, 127.

Peters, J. H., Shepard, C. C., Gordon, G. R., Rojas, A. V. and Elizondo, D. S. (1976). The incidence of DDS resistance in lepromatous patients in Costa Rica: Their metabolic disposition of DDS. Int.J.Lepr. 44, 143.

Riddell, R. W. (1960). Studies on ethionamide (TH 1314) in Great Britain. Trans. 19th Conf. Chemother. Tuberc. (Vet. Adm. Washington), 266.

Rist, N. (1960). L'activité antituberculeuse de l'Ethionamide (L' alpha-éthylthioisonicotinamide ou 1314 Th). Etude expérimentale et clinique. Adv. Tuberc. Res. 10, 69.

Rist, N., Grumbach, F. and Libermann, D. (1959). Experiments on the antituberculous activity of alpha-ethyl-thioisonicotinamide. Am. Rev. resp. Dis. 79, 1.

Rist, N., Grumbach, F., Libermann, D., Moyeux, M., Cals, S. and Clavel, S. (1958). Un nouveau médicament antituberculeux actif sur les bacilles isoniazido-resistants: le thioamide de l'acide $\alpha$-ethylisonicotinique. Etude éxperimentale. Rev. Tuberc. (Paris) 22, 278. 
Rollier, R. and Rollier, M. (1972). Traitement de la lèpre lépromateuse par l'éthionamide. Maroc.Med.52, 148.

Rossi, M. and Rübsamen, K. (1977). Determination of prothionamide and its sulphoxide metabolite in physiological fluids by quantitative thin-layer chromatography. $J$. Chromatogr. 132, 562.

Shepard, C. C. (1969a). Minimal effective dosages in mice of clofazimine (B. 663) and of ethionamide against Mycobacterium leprae. Proc. Soc. exp. Biol. Med. 132, 120.

Shepard, C. C. $(1969 b)$. Further experience with the kinetic method for the study of drugs against Mycobacterium leprae in mice. Activities of DDS, DFD, Ethionamide, Capreomycin and PAM 1392. Int.J.Lepr. 37, 389.

Shepard, C. C. (1976). Combinations involving dapsone, rif ampin, clof azimine, and ethionamide in the treatment of M. leprae infections in mice. Int. J. Le pr. 44, 135.

Waters, M. F. R., Rees, R. J. W., Pearson, J. M. H., Laing, A. B. G., Helmy, H. S. and Gelber, R. H. (1978). Rifampicin for lepromatous leprosy: nine years' experience. Br. med. J. $i$, 133. 